\title{
Számítógéppel segített hiba-lehetóség és hiba-hatás elemzés
}

\author{
Johanyák Zsolt Csaba
}

Az elöadós két részre tagolódik. Azz elsõ rész a konstrukciós hiba-lehetōség és hiba-hatás elemzés (FMEA) eredetének és céljainak ismertetése után bemutatja a konstrukciós FMEA módszerét. A második rész a számitógépes támogatós szükségességét emeli ki, valamint taglalja - az elóadó doktoranduszi kutatási témáját képezõ - a CAD rendszerrel integrált konstrukciós FMEA szoftver megvalósittásának alapelveit és modelljét.

Az erősödő versenyhelyzet és a növekvő pénzügyi kockázat minden vállalatot arra késztet, hogy az általa végzett tevékenység minőségét szabályozó és irányító rendszerbe minél több olyan mechanizmust építsen be, mely felismeri a lehetséges hibákat és azok következményeit még a termék vagy szolgáltatás elöállitási folyamatának kezdeti szakaszában, minimálisra csökkentve ezáltal a szükséges változtatások költségeit. a hiba-lehetőség és hiba-hatás elemzés (FMEA) kiválóan alkalmas e feladat ellátására.

\section{Mire jó az FMEA?}

Az FMEA-t az USA-ban fejlesztették ki a repülögépipar és ürhajózás-technika területén, ahol a legkisebb hiba is végzetes következményekkel járhat, ezért igen nagy hangsúlyt helyeznek a megelözésre. A 70-es években már széleskörüen alkalmazták az autóiparban, ami hamarosan maga után vonta az eljárás szabványosítását [1] is. Az autógyártó cégek nagyon szigorú elvárásokat támasztanak beszállítóik minőségbiztositási rendszereivel szemben (pl. [2]), ez jelentős mértékben hozzájjárult az eljárás széleskörü elterjedéséhez. Így a minőségirányitással és a minőségügyi rendszerek elemeivel foglalkozó ISO 9004 már a tervezés minösitésének és jóváhagyásának egyik lehetséges eszközeként ajánlja ezt a módszert. Az elemzés célja az egyes hibalehetöségek felismerése a termék életciklusának minél korábbi szakaszában, a hiba előfordulásának megelőzése, és az esetlegesen előforduló hibák vevőhöz való eljutásának megakadályozása, $s$ ezáltal egyrészt közvetlen költségmegtakaritás elérése, másrészt a vállalat jó hírnevének megőrzése. A megvizsgált terület szempontjából az elemzés két alaptípusát különböztetjük meg:

- Konstrukciós FMEA. Célja a konstrukciós megoldásokból és a tervező által készített elöirásokból eredő hibák feltárása és kiküszöbölése. 
- Folyamat FMEA. Célja a gyártás során az anyagbeszerzéstől a csomagolt áru kiszállitásáig a gyártási technológiából, anyag-, gép-, és eszközhibából, valamint emberi mulasztásból eredö hibák feltárása és kiküszöbölése.

A szabvány csak az eljárás keretét határozta meg, tág területet hagyva a körülményekhez, feladatokhoz való rugalmas alkalmazkodás számára, így az idők folyamán különböző FMEA altípusok fejlödtek ki. Ezek közül széles körben alkalmazzák a termék-, a rendszer- és a környezet elemzésre szakosodott változatokat.

Az elemzés folyamata hasonló az összes típus esetén, ezért a továbbiakban csak a konstrukciós FMEA-val foglalkozunk.

\section{Konstrukciós FMEA}

Az elemzés folyamata három szakaszra tagolódik (1. ábra). A módszer csoportmunkára épül, ezért a hatékonyság érdekében különösen fontos szerepe van az elökészitésnek. Ez magába foglalja a csoport összetételének és létszámának kialakítását, valamint szükség esetén a résztvevők képzését. Az oktatást nem szabad elhanyagolni, mert mint minden új módszer esetében, itt is csak akkor számíthatunk sikerre, ha mindenki hisz az eljárás jóságában, és nem csak a fönöki utasitás kényszerének engedelmeskedve alkalmazza azt. A második szakasz a konstrukció első átvizsgálását foglalja magába. Itt első lépésként alkotó elemeire bontják azt, majd minden egyes elem esetén megkeresik a hiba lehetőségeket, azok okait és következményeit, felállitva ily módon az ún. elem-hiba-okkövetkezmény láncolatokat, melyek egy-egy összetartozó információsort kötnek egy csoportba. Minden egyes láncolatot három szempont szerint külön-külön értékelnek 1 és 10 közé eső számokkal, figyelembe véve a jelenlegi állapotot, azaz a már beépitett ellenörzési és megelöző intézkedéseket. Többféle módszer terjedt el a három kockázati méröszám által nyứjtott információ értelmezésére. A legáltalánosabb a kockázati tényező (KT) kiszámitására épül, melyet aztán egy Pareto elemzés keretén belül használnak fel. A Pareto elemzés célja lényegében egy

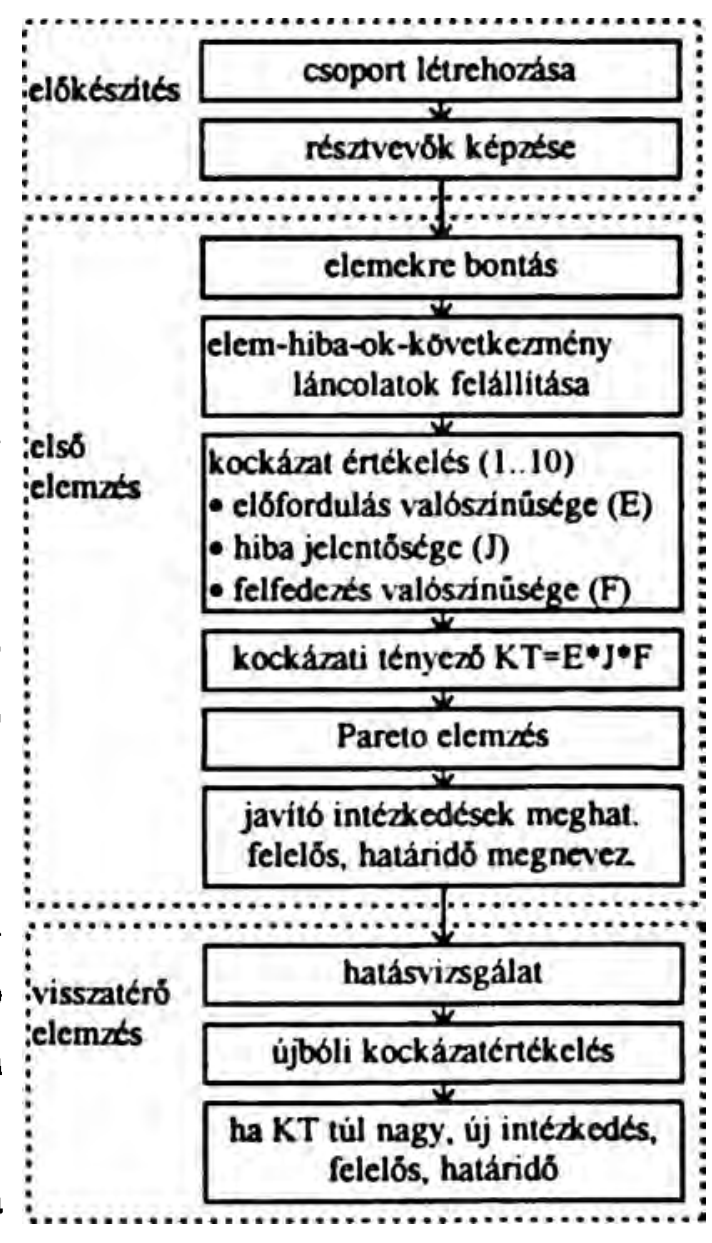

1. ábra. Az elemzés lépései fontossági sorrend felállitása a különböző láncolatok között. A megállapított sorrendet követve a munkacsoport minden egyes láncolat esetén meghatározza a kockázat csökkentése érdekében szükséges 
teendőket (terv átdolgozása), a végrehájtásért felelös személyt és a megvalósitás határidejét. A harmadik szakasz a visszatérő elemzés, ami a határidő lejártakor következik. Ekkor megvizsgálják az elöírt intézkedések megvalósitását és annak hatásait. Újból kiszámolják a kockázati számokat és magát a kockázati tényezöt. Amennyiben ennek értékét még mindig túl magasnak találnák, újabb intézkedést javasolnak a probléma megoldására. Kedvezötlen esetben a harmadik szakasz egy láncolat esetén többször is megismétlődhet. A konstrukció gyakorlati megvalósítása, legyártása csak azután következhet be miután a munkacsoport az összes kockázati tényezöt elfogadhatóan alacsony értékünek itélte meg.

\section{Számítógépes támogatás}

Az FMEA-t alkalmazó vállalatok többsége két oldalról is nyomás alatt áll. Egyrészt a minőségügyi és biztonságtechnikai követelmények teljesitése érdekében törekedni kell arra, hogy az elemzés lehetöleg mindenre terjedjen ki, másrészröl ott vannak a szoritó határidök és pénzügyi keretek, és az FMEA hatása csak közép vagy hosszútávon mutatkozik meg. A hagyományos módon végrehajtott eljárásnak számos gyenge pontja van. Körülményes a dokumentálás, nehézkes a korábban elvégzett elemzésekbe beépitett tudásanyag visszakeresése. Az erőforrások optimális kihasználása ebben az esetben csak a számitástechnika bevetésével érhető el. Egy ilyen célból készült szoftverrendszer legalább a következö szolgáltatásokat kell nyújtsa:

- adatbázis-kezelési lehetöségek az egyes alkotó elemekhez kapcsolódó típushibák eltárolására, visszakeresésére, valamint az adatok karbantartására;

- hiba lehetőségek, okok, következmények és javitó intézkedések listájának automatikus elöállítása, ha egy olyan elemet vizsgálunk, melyre korábban már végrehajtottuk az elemzést;

- határidö-figyelés;

- adatvédelem és -titkositás;

- elemzés kinyomtatása;

- könnyen tanulható és kezelhető, felhasználóbarát felület.

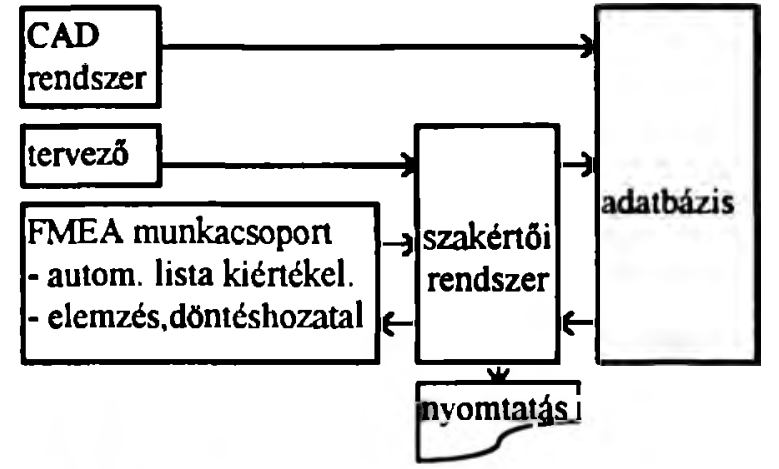

2. ábra. CAD rendszerrel integrált FMEA programcsomag

\section{Tudásalapú FMEA rendszer}

Még ma is nagyon gyakran elöforduló probléma, hogy ha egy sok tapasztalattal rendelkező szakember megválik a vállalattól, hamarosan beáll a káosz. Rengeteg részletkérdés nincs dokumentálva, mert vagy nem tartották fontosnak, vagy egyszerüen nem volt rá idỏ. Ilyenkor sok idỏ és pénz kell arra, hogy mindent újra kiderítsenek. Egy másik probléma, hogy az emberek felejtenek, vagy nem ott és akkor jut eszükbe a megfelelö információ amikor arra szükség lenne. A módszer gyenge pontjait felismerve tanszékünk 1994- 
ben elinditott egy projektet egy konstrukciós FMEA programrendszer megvalósitása érdekében. A feldolgozandó tudásanyag sokrétűsége és nagy mennyisége következtében egy CAD rendszerrel integrált tudásalapú szoftver alapelveinek kidolgozása lett célként meghatározva. A rendszer nem helyettesíti az elemzést végző munkacsoport szakértöit, az emberi kreativitás nélkülözhetetlen. A rendszer feladata "mindössze" annyi, hogy könnyebbé, gyorsabbá és hatékonyabbá tegye az elemzést végző szakértő csoport munkáját. A CAD rendszer segítségével a tervező elkészíti a konstrukciós tervet. Ez tartalmazza az egyes elemekre vonatkozó geometriára és anyag-kiválasztásra vonatkozó . Ezek az információk bekerülnek az adatbázisba, ami lehet önálló vagy a vállalati információs rendszer része. A konstrukció teljes leirásához szükségesek még az egyes elemek feladatát, müködését meghatározó információk. Ezt a tervező adja meg a szakértői rendszer interfészprogramja segítségével. A tudásalapú rendszer elemenként haladva elöveszi a tervezési információt az adatbázisból, megvizsgálja, hogy készült-e már ugyanilyen, vagy hasonló paraméterekkel rendelkező elemre vonatkozó elemzés, és ha igen akkor automatikusan közli az elemzö csoporttal a korábban felismert hibalehetöségeket, okokat és következményeket, azok értékelését, esetleg a korábban tapasztalt meghibásodásokhoz kapcsolódó költségeket, és felkínál egy vagy több, korábban már bevált javító intézkedést. A munkacsoport ezt elfogadja, vagy az időközben szerzett újabb tapasztalatokra, változásokra való tekintettel megváltoztatja esetleg elveti azt. Ezután következik a kockázati tényezök szokásos értékelése, amit a szakértő rendszer az adatbázisban található minőség költség adatok kikeresésével segit, majd egy automatikus Pareto elemzés a határidők fontossági sorrendben történő megállapitása érdekében. Amennyiben a rendszer nem talál ugyanolyan vagy hasonló elemre vonatkozó korábbi adatot, az elemzés a hagyományos módszerrel folytatódik. Az FMEA eredménye mindig hozzáadódik az ismeretbázishoz. Az alkalmazott modell talán legérdekesebb kérdése a hasonlóság vizsgálata és a hiba-lehetőség lista összeállítása. Egy idő után a tapasztalati tudást jelképező információhalmaz meglehetősen nagy méreteket ölt, ezért egy olyan adattárolási módszerre van szükség, mely biztosítja úgy a gyors elérhetőséget, mint a folyamatos bővíthetőséget. Erre fastruktúraszerü objektumhierarchia kínálkozott a legjobb megoldásnak. A fastruktúra minden "levele", azaz végpontja egyegy elem azon tulajdonságait tartalmazza, melyek csak rá jellemzőek. A csomópontok csoportokat jelképeznek. A csoportok olyan tulajdonságok tárolására szolgálnak, melyek a csoport minden tagjára jellemzőek. A tárolt információmennyiség növekedésével a hierarchia többszintűvé válik. Egy új elem vizsgálata esetén'a rendszer az elöre megadott tulajdonságok alapján megpróbálja besorolni azt valamelyik csoportba. Ha ez sikerül, és az adott csoportban talál egy a vizsgálat tárgyával teljesen megegyező elemet, akkor készit egy teljes elem-hiba-ok-következmény láncolat listát a korábbi tapasztalatok alapján. Ha teljesen azonos elemet nem talál a rendszer, de valamelyik csoportba sikerül besorolni az elemet a hasonlósági kritériumok alapján, akkor egy részleges, a csoportra jellemző listát kapunk. Ez természetesen kisebb értékü mint az elöző, de kiindulópontként nagy segítséget nyújthat. Amennyiben sehova se sikerül besorolni az új elemet, a rendszer egy új föcsoportot nyit számára. Természetesen egy-egy elem 
besorolásánál és hasonlósági vizsgálatánál nem vehetjük figyelembe annak összes tulajdonságát. Ezért felelősségteljes szerepe van annak aki megállapítja, hogy egy adott alkalmazási területen melyik az a néhány jól körülhatárolt tulajdonság típus, amit figyelembe veszünk a besorolás folyamán.

A projekt jelenleg a szakértöi rendszer kidolgozásának fázisában van. Az alkalmazott szakértői shell a Kappa-PC 2.3.

\section{Irodalomjegyzék}

[1] DIN 25448: Ausfalleffektanalyse (Fehler -Möglichkeits- und -Einfiuss - Analyse), 1990.

[2] Q101 Qualitatssystemrichtlinie, Ford AG, Köln, 1985.

[3] Deckers, Jürgen - Schäbe, Hendrik: FMECA rechnergestüztz erstellen, Qualitat und Zuverlässigkeit, 1992, s. 366-369.

[4] NedeB, Christian - Nickel, Joachim: FMEA wissensbasiert erstellen, Qualitat und Zuverlässigkeit, 1993, s. 689-693.

[5] Leistungsfahiges FMEA-System, Qualitat und Zuverlässigkeit, 1994, s. 235.

[6] Pfeifer, tilo - Spiekermann, Jürgen - Zenner, Thomas: Konsequente Fehlervermeidung durch FMEA, Qualitat und Zuverlässigkeit, 1994, s. 285-291.

Johanyák Zsolt Csaba, minöségügyi mérnök

Gépipari és Automatizálási Müszaki Főiskola, Informatika Tanszék, H6001 Kecskemét Pf. 91.

Tel.:-36-76-481 291

Fax:-36-76-481 304

e-mail: csaba@gandalf.gamf.hu 